\title{
Land tenure
}

The experience of Madagascar

Decentralising

land management

André Teyssier

Projects to take control of vast areas of arable land in Southern countries have revived interest in public policies to improve land tenure security. Often based on principles inherited from colonial times and focusing on the issue of land titling by government departments, these policies are now unsuited to the growing social demand for improving land tenure security in Southern countries, especially in sub-Saharan Africa. Indeed, the advance of the market economy, the growth of cities, the decline of customary authorities and forms of regulation and the progressive commodification of land are all at the root of a growing need to secure land rights in writing. This need is all the greater because rural societies are faced with the land acquisition strategies pursued by major economic operators.

Between the preservation of long-standing land policy instruments that have shown their limits, and the promotion of community regulations, some Southern land tenure policies are exploring the middle ground combining the recognition of social land management practices and the formalisation of land rights by the public authorities. This is the case in Madagascar, which launched a land policy reform in 2005 based on the decentralisation of land management powers.

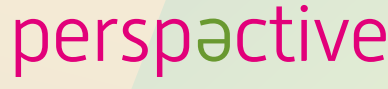

Through Perspective, CIRAD provides the opportunity to explore new avenues for discussion and action based on research, without presenting an institutional position.

\section{"Small papers" in response to the failure of land titles}

Madagascar has inherited the state-ownership land tenure system established by French colonisation, and inspired by the Australian Torrens Act: the land is presumed to belong to the State, which grants land titles to those who cultivate it. Recording details in a register, the State recognises clear title in the form of land rights that are enforceable against third parties. This system met the requirements of the time: establishing an internationally recognised legal basis for the land-grabbing that accompanied French colonisation, and granting land titles to certain entrepreneurs investing in so-called "modern" agriculture.

As the registration process is complex -24 stages and an average duration of six years -, in 110 years the government has only delivered 400000 titles in a country counting some 5 million agricultural and urban land parcels. The poor state of the land registry authorities in addition to the deterioration of archives, the frequent disappearance of boundary markers on the land and in some cases the absence of any 
identified owner, all raise questions as to what property actually means.

The failure of this system has some serious consequences: the registration process is inaccessible to most applicants; users are rarely assured of their rights, especially as customary regulations are declining and the threat of despoilment is on the increase; investment is becoming risky; the courts are saturated with land disputes; and the lack of knowledge regarding the actual occupation of land is hampering the establishment of land taxes needed to enable local authorities to support development needs.

Faced with this progressive paralysis, users have developed local methods for recognising rights, known as "small papers". This system involves setting down one's rights on paper and attempting to persuade a local public institution (the municipality or fokontany) to authenticate it by stamping it. Despite the lack of any national regulations, these papers are drawn up in exactly the same way throughout the country (identity of the title holder, validation of the title by the neighbours, estimated surface area, information on the type of land occupancy and use, and on the nature of the rights). These papers are a less costly way of formalising land transactions and assure a first level of security. The land market therefore consists in practices that involve local authorities, without the government necessarily being formally engaged or even informed. These practices are an alternative to the exclusively sovereign conception of land management. The 2005 land reform was inspired by this, giving municipalities new powers for local land management.

\section{Presumption of ownership and local land offices}

In 2003, civil society organisations instigated a national debate and pleaded for a simplification of the registration process for land titles. In response, the government set up a task force on land policy reform. Open to local councillors, members of parliament and senators, heads of regions and representatives of farming associations, this group is outside the influence of land corporations and trade lobbies. In late 2004, it put forward the idea of granting municipalities the power to validate property rights by emitting not titles, but land certificates, according to local, public, adversary procedures.

In 2005, a land policy letter confirmed this approach. It provided for the creation of the "guichet foncier", or land office, a municipal department in charge of recording and updating land rights according to simplified procedures. It took into consideration the dearth of public financial resources and the limited finances of populations. It was followed by Law 2005-019 laying down the status of land, which includes a major innovation: untitled private property rights may now be legally recognised. Taking into account "land held by virtue of untitled property rights", this law removes the presumption of State ownership. Untitled land that has nevertheless been developed, cultivated or built on by generations of users is no longer presumed to be State property. The "personal or collective tenure" attesting to occupation is sufficient for users to be recognised as owners.

This law announces a combined land management system: the formalisation of titled land falls within the remit of the national government; the formalisation of untitled land through certificates is a new power given to municipalities. Issued by the municipal land office and recognised by the State, the certificate is a document that guarantees permanent property rights. Users must choose the means of formalising their land rights.

All municipalities may open a land office. Run by municipal employees, this department organises procedures for recognising parcels of land at the request of users, manages land information and informs the national government of certificates issued. The operating costs are covered by the municipal budget and by revenue from these certificates. If necessary, the mechanism may be operated within an inter-municipal framework.

The procedure for recognising land rights is set out in Law 2006-31 regarding untitled private property. For each application for a certificate, a local recognition commission composed of elected representatives of the municipality and the communities (fokonolona), makes a report in the area concerned recording the rights asserted along with any objections. Further to this process, if there is no objection, the office employee then prepares a certificate that will be signed by the mayor. The boundaries of certified plots of land are recorded on a local land use plan (PLOF), a map of the legal statuses of the land which details the location of private and State-owned plots and, by default, the area of competence of the municipal office (untitled private property and municipal land). The PLOF is drawn up preferably using satellite images or aerial photos, on which the users themselves outline the plots to be certified, according to visual markers such as paths, watercourses, characteristic 
Land certificates are formalising individual

or group property rights within a a lower cost means of relatively short time.

trees, rocky outcrops or irrigation channels between parcels, etc. This means that national government departments do not have to be involved and dependence on the Government can be reduced, as can the costs and duration of procedures.

Land certificates are a lower cost means of formalising individual property rights within a relatively short time, but they may also be issued in the name of a group in order to grant rights to forest or pastoral resources that are used collectively

The municipalities have rapidly shown great interest in land offices, as illustrated in the following graph (fig. 1). In less than three years, 300 Malagasy municipalities, or $20 \%$ of the total number, have set up land offices with the support of the international community. Half of all Malagasy municipalities are expected to have one within the next two years.

The municipalities that now have land offices received 100000 requests between 2006 and 2009 , and issued 50000 certificates, in other words $80 \%$ of all land documents (titles and certificates) delivered throughout the country. In 2008 and 2009, as many certificates were established for less than $20 \%$ of the national territory as titles for the whole country over the last 30 years.

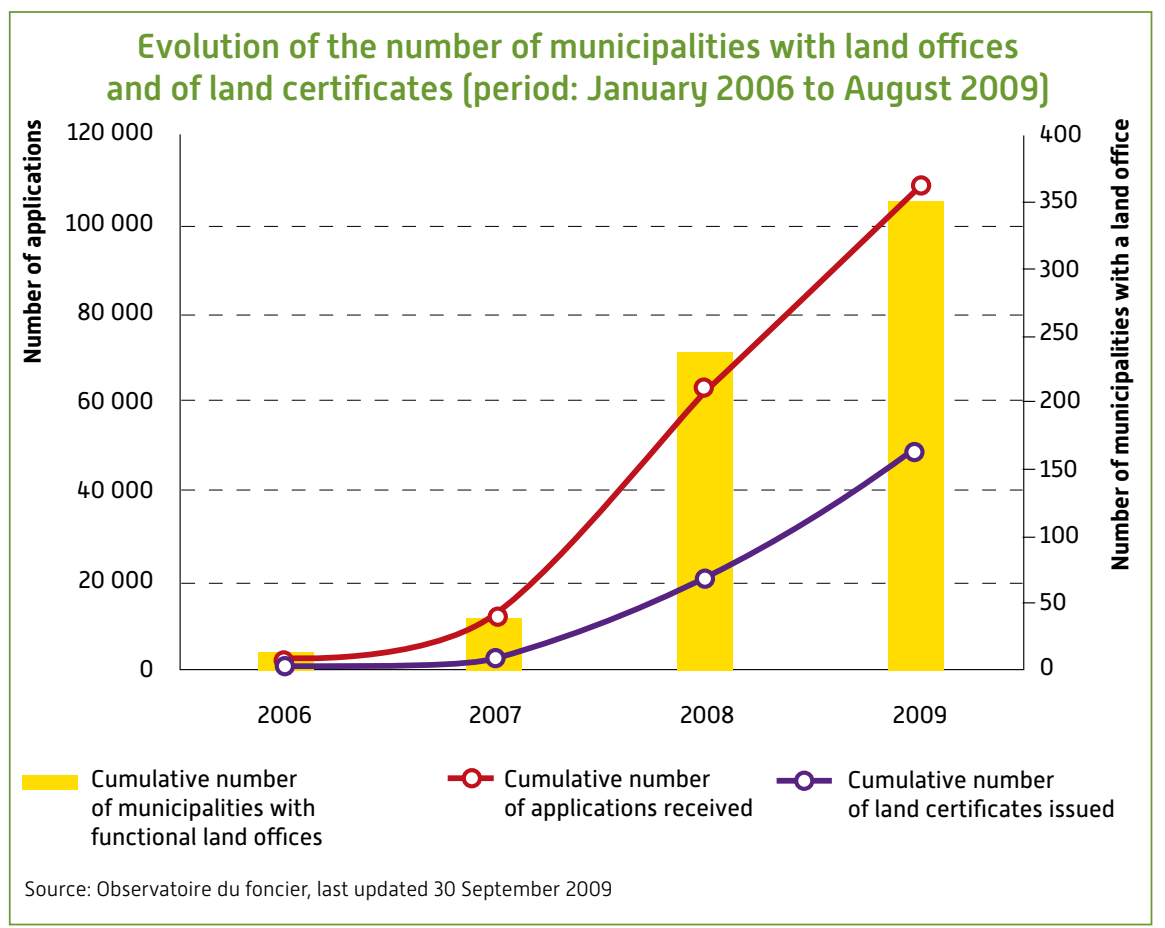

This interest in land offices is primarily explained by the clear improvement in public land management in terms of costs and waiting periods: the average cost of a certificate is 10 euros, compared to 370 euros for a title, and the process takes six months instead of six years.

\section{Deploying the land reform across the whole country: a challenge}

These promising results are not enough to mask the serious constraints facing the future of the new Malagasy land policy.

These constraints vary in nature. They are primarily technical and operational: the ruin of the land conservation offices and topography departments has accelerated the deterioration of land plans and files and prevents them from being updated. It means that existing land titles cannot be positioned in order to inform municipalities of their area of competence. Furthermore, the costs of acquiring the images needed to draft PLOFs exceed the financial capacities of municipalities.

But the main constraint concerns the reticence of the State administration regarding the process of decentralisation, which is seen by some civil servants as a loss of status, power and revenue. Part of the land administration is developing resistance strategies: disparaging communication with ministerial bodies and users; attempts to put the municipal offices under the supervision of deconcentrated departments; and maintaining State-ownership status that does not fall within the authority of the municipalities, even if this status is obsolete (registered indigenous reserves, cadastral operations that have remained incomplete for several decades, colonisation areas, etc.).

Finally, the erratic functioning of municipalities, linked to municipal governance that is often hampered by the insufficient capacity of municipal councillors and employees, remains a major constraint. Experience shows that the functioning of land offices depends largely on the smooth running of the municipal authorities.

Deploying this land policy across the whole country therefore implies simultaneously taking up several challenges.

Training is one of the keys to the future of the land tenure reform. The opening of several hundred offices requires new skills and the professionalisation of municipal employees, the administration and support organisations. The structuring of a new profession should be envisaged in such a way as to make the municipal office employee a local civil servant who has received specific training that is endorsed by a nationally-recognised qualification system. 
This document is the result of research conducted in partnership within the different Malagasy ministries responsible for the implementation of the new land policy, and especially the National Land Programme and the project on the Lake Alaotra catchment area. It has led to the publication of several articles, including:

Teyssier A., Raharison H., Ravelomanantsoa Z., 2008. La réforme foncière de Madagascar ou le pari de la compétence locale. In Sandron F., Population rurale et enjeux fonciers à Madagascar, Cite / Karthala, p. 19-33.

Teyssier A., Ravelomanantsoa Z 2008. Madagascar. Une réforme face à la faillite du système Torrens. Études Foncières $n^{\circ} 134$ July-August 2008: 34-38.

Teyssier A., Andrianiriana Ratsialonana R., Razafindralambo $\mathrm{R}$ Razafindrakoto Y., 2009. Décentralisation de la gestion des terre à Madagascar : processus, enjeux et perspectives d'une nouvelle politique foncière. In Colin J.-P. et al. Les politiques de reconnaissance des droits fonciers. Du cadre légal aux pratiques locales. IRDKarthala, p. 273-297.

\section{perspəctive}

Editor:

Patrick Caron, Director of Research

and Strategy

Coordination:

Corinne Cohen, Department fo

Scientific and Technical Information

Graphic design:

Patricia Doucet, Communication office Translation:

Anna Kiff

Layout:

Laurence Laffont

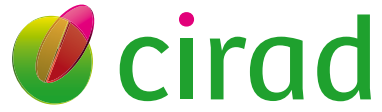

LARECHERCHE ACRONOMIQUE POUR LE DÉVELOPPEMENT

42 , rue Scheffer

75116 Paris. France

www.cirad.fr
Furthermore, the reform process must maintain considerable capacity for innovation in order to overcome the technical constraints and to limit the costs of setting up and running offices. As the main elements of the legal framework have been put in place, it is now necessary to move on to the next step: supporting the municipalities in developing their own land and fiscal policies. The tools of decentralised land management can be used to stimulate taxation - and thereby perpetuate the running of the offices -, to integrate the management of forest, pastoral or mining resources, to take into consideration the customary regulations still in force, to plan the rural or urban development of territories and, potentially, to manage land use by agro-industries.

The political challenge remains the biggest, depending as it does on whether or not the government is in favour of decentralisation. A permanent mechanism for monitoring, supporting and advising municipalities is clearly essential. Will it be entrusted to a government department, at the risk of stifling the strategy, or to the local authorities, whose resources are unreliable? The debate continues, but it is becoming clear that the institutional design of the land reform depends on the political will for and the feasibility of the reform, which are themselves linked to the political sphere's perception of its validity according to different interests, ideological models and administrative constraints (the organisation of taxation and the nature of the competences available), etc. Depending on the context and the moment, politics may encourage decentralisation or, to the contrary, the recentralisation of land management.

\section{Lessons and specificities of the Malagasy experience}

The Malagasy experience opens up perspectives that could inspire the reform of land policies in sub-Saharan African countries. The partial shift away from the foundations of colonial policy - removing the presumption of State ownership and the decentralisation of land management - has led to significant progress in terms of public services for guaranteeing and managing land rights. However, the specificities of the Malagasy reform must be examined before it can be considered as a model.

These radical changes were made in a favourable political context, with the decentralisation of land management heralded as a development choice. This kind of political will is unusual as it may run counter to the interests of the public authorities and the State employees responsible for land administration. For example, if it wants to attract investment or establish agricultural or tourist industries, the central State will prefer to have full control over land management, since the decentralisation of land management could jeopardise its plans. Similarly, land corporations are unwilling to see some of their powers taken away from them. Only a strong political will, possibly supported by social demands, can mitigate the effects of State-ownership approaches and defensive government strategies.

The relative decline of customary powers and the high social demand for written land rights are some of the other Malagasy specificities that must be taken into account before any plans are made to extend this experiment.

Finally, it seems that a reform based on an innovation as radical as the decentralisation of land management must give priority to training the human resources concerned. Not only the local councillors and office employees, but also the legal, technical and regional authorities must fully understand these institutional innovations. Land management decentralisation processes must therefore be accompanied by ambitious training courses. This training must go beyond the framework of the land sector alone, as it would be unrealistic to promote decentralised land management in favour of municipalities that are deprived of their budget and function in an undemocratic way.

The challenge is therefore to increase the overall competence of the municipal level in terms of local governance and regional development.

\section{Quelques mots sur... André Teyssier}

André Teyssier holds a PhD in geography and is a researcher in the TETIS joint research unit (on territories, environment, remote sensing and spatial information, http://tetis.teledetection.fr/], where he focuses on public policies to improve land tenure security. Since 2004, he has been an adviser to the Malagasy government on the design and implementation of the land reform and today works with the Malagasy Land Observatory.

andre.teyssier@cirad.fr 